\title{
Access to Cooperative Education Programs and the Academic and Employ- ment Returns by Race, Gender, and Discipline
}

\section{Dr. Joyce B. Main, Purdue University, West Lafayette}

Joyce B. Main is an Assistant Professor in the School of Engineering Education at Purdue University. She holds a Ph.D. in Learning, Teaching, and Social Policy from Cornell University, and an Ed.M. in Administration, Planning, and Social Policy from the Harvard Graduate School of Education.

\section{Dr. Matthew W. Ohland, Purdue University and Central Queensland University}

Matthew W. Ohland is Professor of Engineering Education at Purdue University and a Professorial Research Fellow at Central Queensland University. He has degrees from Swarthmore College, Rensselaer Polytechnic Institute, and the University of Florida. His research on the longitudinal study of engineering students, team assignment, peer evaluation, and active and collaborative teaching methods has been supported by over $\$ 12.8$ million from the National Science Foundation and the Sloan Foundation and his team received Best Paper awards from the Journal of Engineering Education in 2008 and 2011 and from the IEEE Transactions on Education in 2011. Dr. Ohland is past Chair of ASEE's Educational Research and Methods division and a member the Board of Governors of the IEEE Education Society. He was the 2002-2006 President of Tau Beta Pi.

\section{Nichole M. Ramirez, Purdue University}

Nichole M. Ramirez is a graduate student in the School of Engineering Education at Purdue University. She received her B.S. in aerospace engineering from The University of Alabama and her M.S. in aviation and aerospace management from Purdue University. She is a former recipient of the Purdue Doctoral Fellowship. In addition to cooperative education research, she is also interested in studying student choice and migration engineering and technology.

\section{Trina L. Fletcher, Purdue University}

Trina Fletcher is an Engineering Education doctoral student at Purdue University. Her research focus includes the recruitment and retention of underrepresented groups in STEM education with a special focus on women. Prior to Purdue, she spent time in industry along with completing research and writing on STEM education related topics. She holds a Bachelor's degree in Industrial Technology and a masters degree in Engineering Management. Follow her on Twitter at STEMGenius. 


\title{
Access to Cooperative Education Programs and the Academic and Employment Returns by Race, Gender, and Discipline
}

\begin{abstract}
A cooperative education program (co-op) in engineering is a partnership between an academic institution and an employer designed to engage students in practical engineering experience through rotations of full-time employment and course study. Co-op employment provides students with discipline-relevant professional experience and early entry into the engineering labor force while serving as a recruitment tool for co-op companies. While much is known about the value of cooperative education programs, relatively little is known about why there are different rates of participation by race/ethnicity and how recruitment and pre-screening practices influence the diversity of students who participate in co-op programs. The objectives of this research project are to identify factors that influence student access to cooperative education programs and to determine the educational and employment returns associated with participation. Data include comprehensive longitudinal academic student records from multiple institutions, as well as surveys and interviews of students from a large research-intensive institution. Research findings will lead to the development of strategies to further enhance co-op recruitment and engagement of engineering students from a broader range of backgrounds, interests, and experiences as a pathway to increase the overall diversity of the professional engineering labor force.
\end{abstract}

\section{Background}

Cooperative education programs in engineering are designed to provide students with professional experience relevant to their academic discipline in alternating cycles between paid full-time employment and traditional full-time classroom education. Cooperative education programs (co-op) are work opportunities for undergraduate students organized in partnership with industry based organizations, ${ }^{1}$ which can also be referred to as Work-Integrated Learning (WIL). ${ }^{2-3}$ Ordinarily, academic institutions facilitate the application process and connection between students and potential employers. The eligibility requirements are institution-specific and can vary by discipline or at the discretion of the co-op employer; however, many universities commonly require a minimum grade point average (GPA) for co-op participation. Since co-op programs have minimum GPA and other eligibility requirements, it is critical to identify how requirements influence the participation of students across race, gender, and socioeconomic status.

It is well known that there are disparities in college access and persistence in engineering by race/ethnicity and socioeconomic status, and that more engineering professionals are needed to meet the growing demands of the labor market and to maintain the nation's competitiveness in technological and scientific areas. The benefits associated with co-ops documented in previous studies, including higher grades and graduation probabilities, suggest that co-op participation can be an effective method for improving the academic outcomes of engineering students. ${ }^{4-10}$ It is less clear, however, whether these academic benefits are due to co-op participation or to selection processes, and if these benefits vary across gender, race/ethnicity, socioeconomic background, and engineering discipline. Further, it is critical for academic institutions to continue developing strategies to facilitate access and affordability for students from families with lower incomes. Therefore, our research objectives are to determine how participation in co- 
ops influences the academic and employment outcomes of students from various socioeconomic backgrounds across race and gender, as well as to identify predictors and conditions for co-op participation. The knowledge derived from these findings will help students and co-op program administrators better assess the benefits to participation and the conditions that help encourage student participation.

\section{Research Overview}

Our objectives and research questions are summarized below. Figure 1 provides a flow chart overview of the research project.

Objective 1: Identify key predictors for cooperative education participation by engineering discipline.

- Which factors predict co-op participation?

- What types of conditions promote co-op participation?

Objective 2: Evaluate patterns in co-op interest and application rates among first-year engineering students using detailed administrative records and individual student interviews from a large research-intensive institution.

- Are there variations in co-op interest and subsequent program application rates across race, gender, socioeconomic background, and discipline?

- Why are some students more interested in co-ops than others?

- Do some students perceive barriers that discourage them from submitting co-op applications?

Objective 3: Determine the academic and employment returns to co-op engagement.

- Does co-op participation influence persistence, program duration, grades, and are there variations by race, gender, socioeconomic background, and discipline?

- What types of professional development and employment attainment benefits are associated with co-op engagement?

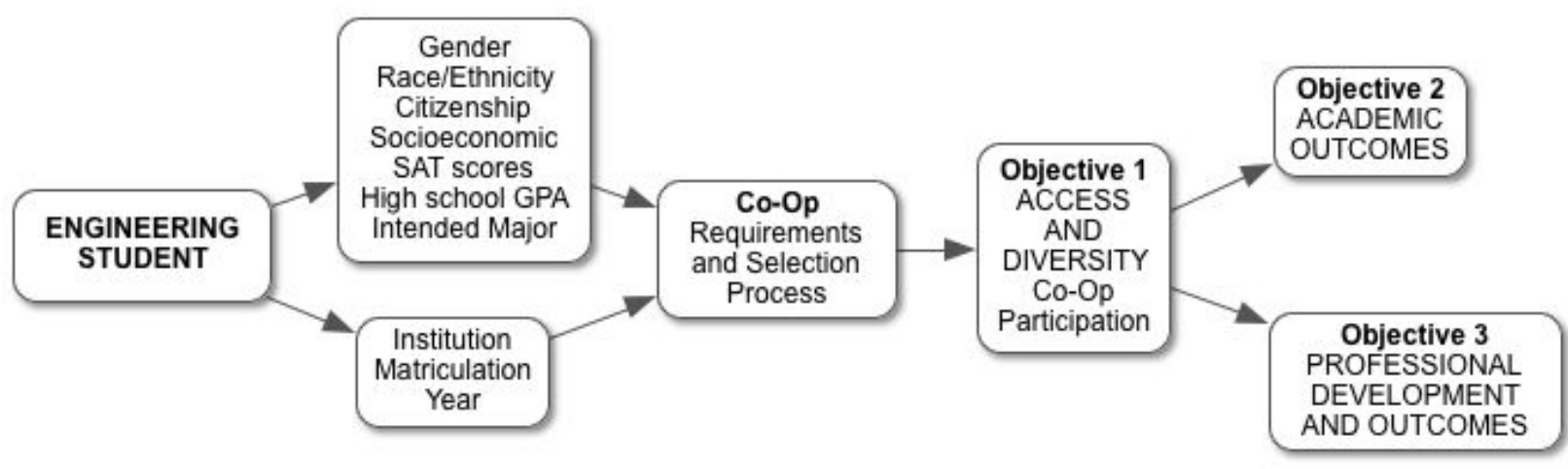

Figure 1: Overview of the research objectives. 


\section{Data}

Our research design incorporates data from two sources: the Multiple-Institution Database for Investigating Engineering Longitudinal Development (MIDFIELD), and administrative records and individual student interviews from a large research-intensive institution in the Midwest. MIDFIELD includes 23 years of student demographic and transcript data from 1987 through 2009 across 6 institutions primarily located in the southeast. Our partnership with the office overseeing the cooperative education program at the large research-intensive institution provides us with detailed administrative records pertaining to co-op recruitment, selection, and participation, as well as access to students for in-depth interviews.

\section{Preliminary Descriptive Statistics}

For our preliminary examination, we limited our sample to students with a first-year grade point average of at least 2.5 and who have declared a major in chemical, electrical, civil, or materials engineering by the first semester of the sophomore year at a MIDFIELD institution across all of the sample years. Based on this sample, an average of $23 \%$ of engineering students in the population participated in a co-op experience. The mean freshman-year grade point average and SAT Math scores are slightly higher among co-op participants (Table 1), which may be partly due to the eligibility requirements associated with the co-op application process. The share of female students who participate in co-ops (0.21) appear to be consistent with the share who do not participate in co-ops. Closer inspection of the data, however, reveals differences in participation rates at each institution (Fig. 2). Institutions in the sample are labeled A through F. Institution $\mathrm{C}$, for example, has a much higher participation rate among women compared to men.

Table 1: Student Summary Statistics

\begin{tabular}{llllll}
\hline \multicolumn{2}{l}{ Panel A: Engineering Students who are Co-op Participants } & & & \\
\hline Variables & Obs & Mean & Std. Dev. & Min & Max \\
\hline Freshman-Year GPA & 6,708 & 3.371 & 0.408 & 2.5 & 4 \\
High School GPA Percentile & 5,299 & 76.51 & 20.26 & 1 & 99 \\
SAT Math Score & 4,916 & 654.0 & 64.9 & 410 & 800 \\
Female & 6,713 & 0.211 & 0.408 & 0 & 1 \\
\hline
\end{tabular}

Panel B: Engineering Students who are Co-op Non-Participants

\begin{tabular}{llllll}
\hline Variables & Obs & Mean & Std. Dev. & Min & Max \\
\hline Freshman-Year GPA & 22,902 & 3.236 & 0.430 & 2.5 & 4 \\
High School GPA Percentile & 13,056 & 79.46 & 18.73 & 1 & 99 \\
SAT Math Score & 16,901 & 646.7 & 71.8 & 290 & 800 \\
Female & 22,931 & 0.214 & 0.410 & 0 & 1 \\
\hline
\end{tabular}




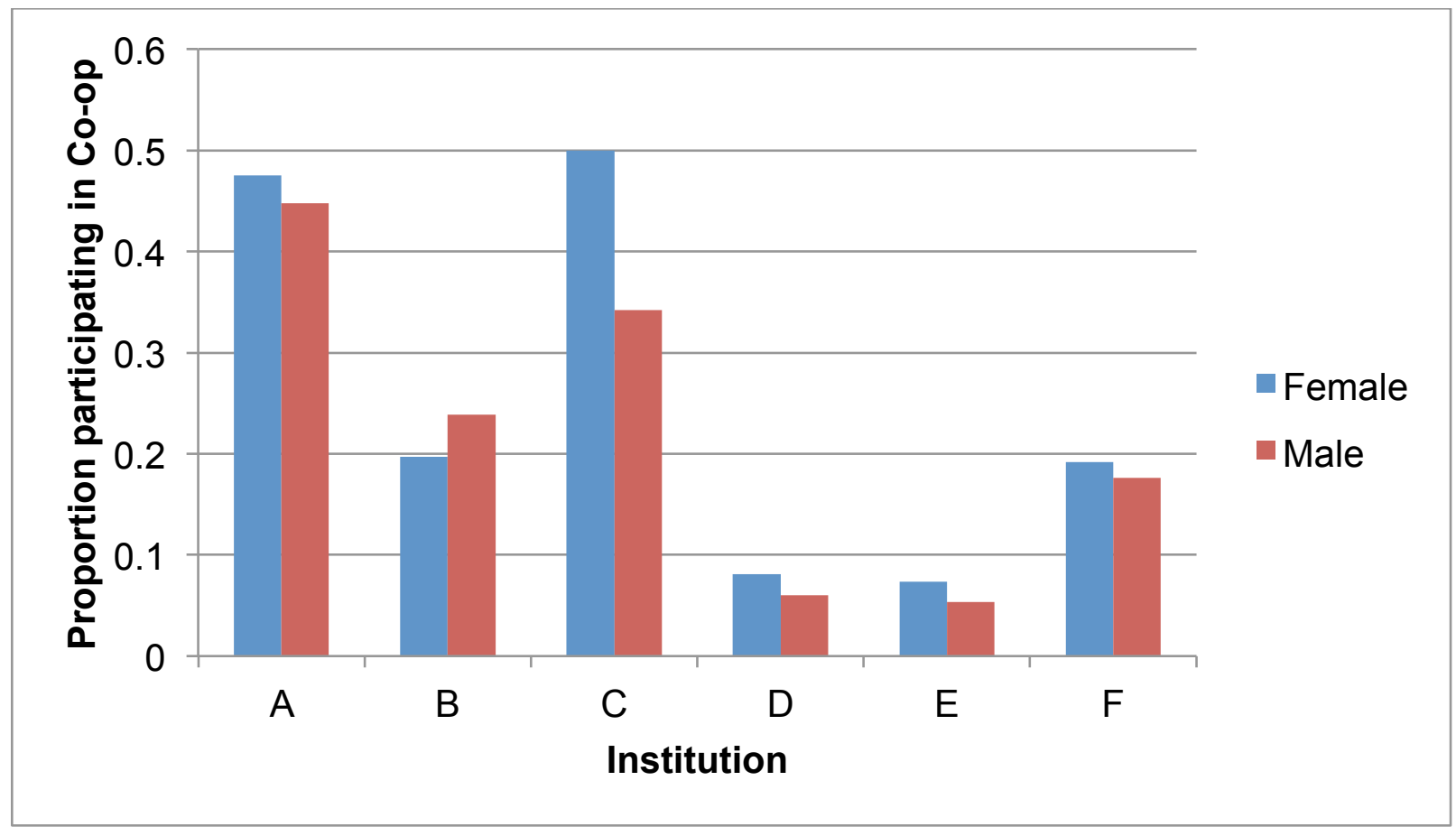

Fig. 2. Co-Op Participation by Gender and Institution

\section{Research Progress}

This grant started on August 15, 2013. Our research team is presently analyzing the MIDFIELD data to identify predictors for co-op participation and the academic returns associated with co-op engagement. We are applying logit regression to predict the likelihood of participating in a coop using several variables selected based on evidence from previous studies, theoretical justification, and available observable data. These include: gender, race/ethnicity, citizenship, SAT scores, grade point average in first-year engineering courses, socioeconomic background as measured by high school economic indicators, and declared engineering major. The model includes institution and year of matriculation as control variables. To determine the academic returns associated with co-op engagement, we will apply propensity score analysis. Propensity score matching is a method of strategic subsampling from among students who participated and who did not participate in a cooperative education program. ${ }^{11}$ Differences in the observed outcome variables, GPA and persistence are calculated from the treated and matched participants, with the average differences being the effect of co-op participation.

\section{Acknowledgements}

The authors thank the National Science Foundation Research in Engineering Education Program (Award Number:1329283) for support of this research. 


\section{References Cited}

1. Haddara, M., \& Skanes, H. (2007). A reflection on cooperative education : from experience to experiential learning. Asia-Pacific Journal of Cooperative Education, 8(1), 67-76.

2. Edgar, S., Francis-Coad, J., \& Connaughton, J. (2013). Undergraduate reflective journaling in work integrated learning : Is it relevant to professional practice ? Asia-Pacific Journal of Cooperative Education, 14(3), 147156.

3. Reddan, G. (2013). To grade or not to grade : Student perceptions of the effects of grading a course in workintegrated learning. Asia-Pacific Journal of Cooperative Education, 14(4), 223-232.

4. Friel, T. (1995). Engineering cooperative education: A statistical analysis of employer benefits. Journal of Engineering Education, 84(1), 1-6.

5. Gardner, P. D., \& Motschenbacher, G. (1997). Early work outcomes of Co-op and Non-co-op Engineers: A Comparison of Expectations, Job Level, and Salary. Journal of Cooperative Education \& Internships, 33(1), 624.

6. Somers, G. (1995). The post-graduation pecuniary benefits of co-op participation: A review of the literature. Journal of Cooperative Education, 31(1): 25-41.

7. Ingram, S., Bruning, S. \& I. Mikawoz. (2009). Career and mentor satisfaction among Canadian engineers: Are there differences based on gender and company-specific undergraduate work experiences? Journal of Engineering Education, 98(2): 333-338.

8. Ingram, S.A. (2005). Making the transition from engineering student to practicing professional: A profile of two women. International Journal of Engineering Education, 21(1): 151-157.

9. Blair, B.F., Miller, M. \& J. Hammer. (2004). The Impact of cooperative education on academic performance and compensation of engineering majors. Journal of Engineering Education, 93(4): 333-338.

10. Parsons, C.K., Caylor, E. \& H. Simmons. (2005). Cooperative education work assignments: The role of organizational and individual factors in enhancing ABET competencies and co-op workplace well-being. Journal of Engineering Education, 94(3): 309-318.

11. Morgan, S. (2007). Counterfactuals and Causal Inference: Methods and Principles for Social Research. New York, NY: Cambridge University Press. 